\title{
Influence of Time of Planting and Method of Curing on Quality Parameters and Nutrient Uptake in Oriental Tobacco (Nicotiana tabacum)
}

\author{
P. Ranga Nethaji* and Y. Reddi Ramu \\ Department of Agronomy, S.V. Agricultural College, Acharya N.G. Ranga Agricultural \\ University Tirupati, Andhra Pradesh, India \\ *Corresponding author
}

\author{
A B S T R A C T
}

\begin{tabular}{|l|}
\hline K e y w o r d s \\
Planting time, \\
Curing methods, \\
Oriental tobacco, \\
Quality parameters, \\
and Nutrient uptake.
\end{tabular}

Keywords

Planting time, Curing methods, Oriental tobacco, Quality parameters,

\section{Introduction}

Tobacco is an important non-food commercial crop and plays a major role in world's economy. It is valued in the world trade mainly for leaf. In the face of mounting evidence on the health hazards of tobacco the consumption is not reduced and it is one of the important source to country's economy. In recent past due to increased awareness and ill effects of smoking the consumers preference has been shifted towards soft blended light type of cigarettes. Oriental tobacco is one such type of tobacco which is used as important component of the world's premium blended cigarettes characterised with small, aromatic, flavourful, readily combustible and has good filling properties. In the world, oriental tobacco is grown in area of 2, 08,000 ha with a production of 1, 87,200 tonnes (tobacco reporter, 2012). It is mostly grown in countries viz. Turkey, Greece, Italy, Bulgaria and Romania on shallow, low fertile soils without much application of chemical fertilizers and irrigation water. Oriental tobacco is a low input requiring, labour intensive and remunerative crop under rainfed conditions. The popularity of blended cigarettes gaining importance for the production of oriental tobacco and efforts are being made to develop suitable agro techniques for the production. The agroclimatic conditions and soils of the 
southern part of Chittoor and Anantapur districts of Andhra Pradesh are similar to the areas where the world's finest quality oriental tobacco was produced. As the crop is grown under rainfed conditions, time of planting with suitable method of curing plays a significant role to get good yield and better quality of leaf.

\section{Materials and Methods}

Field experiment was carried out in farmer's fields of P.T.M. mandal, Chittoor district, Andhra Pradesh to study the effect of time of planting and method of curing on quality parameters and nutrient uptake in oriental tobacco during rabi, 2013. The soil of the experimental field was sandy clay loam in texture having low in available nitrogen (263.4 $\left.\mathrm{kg} \mathrm{ha}^{-1}\right)$, organic carbon $(0.42 \%)$ and medium in available phosphorus $(49.0 \mathrm{~kg} \mathrm{ha}$ $\left.{ }^{1}\right)$ and potassium $\left(225.0 \mathrm{~kg} \mathrm{ha}^{-1}\right)$, alkaline in reaction $\left(\mathrm{pH} 8.1\right.$ ) and $\mathrm{EC}$ of $0.40 \mathrm{dsm}^{-1}$. The experiment was laid out in Randomized Block Design with factorial concept and replicated thrice with 12 treatments, consisted of combination of four planting dates viz., $\mathrm{T}_{1}$ (first fortnight of October), $\mathrm{T}_{2}$ (second fortnight of October), $\mathrm{T}_{3}$ (first fortnight of November) and $\mathrm{T}_{4}$ (second fortnight of November) and three curing methods viz., $\mathrm{C}_{1}$ (open rack sun curing), $\mathrm{C}_{2}$ (25 per cent ventilated polyhouse curing) and $\mathrm{C}_{3} \quad(50$ percent polyhouse curing). The oriental tobacco $c v$ izmir seedlings was transplanted at a spacing of $35 \mathrm{~cm} \times 10 \mathrm{~cm} .20 \mathrm{~kg} \mathrm{~N}, 60 \mathrm{~kg}$ $\mathrm{P}_{2} \mathrm{O}_{5}$ and $60 \mathrm{~kg} \mathrm{~K}_{2} \mathrm{O}$ ha $^{-1}$ was applied through urea, single super phosphate and sulphate of potash as basal at the time of transplanting. Inter culture and weeding were followed as per requirements. Four primings were done in October planted crop and three primings in November planted crop and curing is done as per the treatments. Observations on leaf quality parameters and nutrient uptake were recorded. Curing leaf samples were collected from each plot for chemical analysis. The samples were oven dried at $70^{\circ} \mathrm{C}$ and used for analysis of nicotine, total sugars and potassium content. The nicotine content and total sugars were determined by CORESTA recommended method $\mathrm{N}^{0} 35$ and CORESTA recommended method $\mathrm{N}^{\mathrm{O}} 37$ respectively. The potassium content was estimated by vanadomolybdate yellow method using flame photometer after thorough digestion of the samples with triacid mixture (Jackson, 1973). The color of the tobacco leaves in curing process is varying from green to yellow. The leaf colour is recognized by visual observation based on colour of the leaves. The leaves were classified into 5 grades viz. AG, BG, Kappa, Double Kappa and ND. The detailed description of the grades is presented in table 1 .

Plant samples collected at harvest were dried, ground into fine powder in a Willey mill and used for chemical analysis. Nitrogen, phosphorus and potassium contents were analyzed by the standard procedures outlined by Jackson (1973). The crop N, P and K uptake in $\mathrm{kg} \mathrm{ha}^{-1}$ at the end of experiment was calculated by multiplying the nutrient content $(\%)$ with the dry matter production.

\section{Results and Discussion}

Leaf nicotine per cent was significantly influenced by time of planting (Table 2). Early planting during first fortnight of October recorded lower amount of nicotine $(0.83 \%)$ which was in comparable with the crop planted during October second fortnight $(0.90 \%)$, The lower nicotine content in the October planted crop might be due to excess rainfall received during the crop period which leads to leaching of $\mathrm{N}$ results in lower nicotine accumulation in the leaves. Tobacco leaf with lower nicotine content $(<1 \%)$ would be considered as best quality and fetches premium price to the growers. Delayed planting during November second fortnight recorded the highest nicotine content (1.63\%) which might be due to reduced moisture 
availability during post flowering period resulted in shortened duration of carbohydrate metabolism leading to increased accumulation of nicotine. Moisture stress increases the root growth which increases nicotine synthesis as it is synthesized in roots and translocated to leaves. Increase in the nicotine content due to low moisture availability was also reported by several researchers (Long and Woltz, 1972; Weybrew et al., 1983).

Among the methods of curing, the lowest nicotine content was registered in the 25 per cent ventilated polyhouse curing $(0.99 \%)$ which was significantly lower than the other methods of curing. This might be due to favourable temperature and humidity conditions during curing results in production of cured leaves without excess drying. As excessive dried leaves contain higher amount of total nitrogen which has relation with nicotine content compared to normal cured leaves (Bae, 1987). The highest nicotine content $(1.25 \%)$ was recorded in the open rack curing method (Fig. 1).

Significant interaction effect between the planting time and method of curing revealed that planting of tobacco during first fortnight of October and cured under 25 per cent ventilated polyhouse registered the lowest nicotine content which was in comparable with crop planted in October first fortnight cured under 25 per cent ventilated polyhouse, whereas the highest nicotine content was registered in the crop planted during November second fortnight cured in open rack sun curing (Fig. 2). Total sugars content was high in early planted crop i.e., first fortnight of October (20.01\%) which was statistically on par with crop planted in October second fortnight (19.52\%), while the late planting during second fortnight of November registered lower amount of total sugars $(14.84 \%)$. Generally, well watered or wet season tobacco crops have lower total alkaloids, high starch and reducing sugars than the crop grown during dry season or under moisture stress conditions (Papenfus and Quin 1984; Phillips et al., 1991; Reynolds and Rosa, 1995). With delay in planting time the moisture availability during the post flowering period decreases leading to delayed transition of $\mathrm{N}$ metabolism to carbohydrate metabolism results in lower total sugars. Reduction in the total sugars content with delay in planting time was also noticed by Sreeramulu et al., (2000) and Prasada Rao et al., (2002) in oriental tobacco.

The total sugars has shown significantly higher values in 25 per cent ventilated polyhouse curing method $(19.55 \%)$ compared to other curing methods which might due to increase in the air temperature in polyhouse compared to other curing methods which have profound influence on the starch degradation which hydrolyzes to reducing sugars during curing. The lowest amount of total sugars $(16.19 \%)$ was recorded in the open rack curing method (Table 2 and Fig. 3 ).

Significant interaction effect was found between the time of planting and curing methods (Fig. 4). The highest amount of total sugars $(21.61 \%)$ was recorded in the crop during October first fortnight cured with 25 per cent ventilated polyhouse curing compared to other treatmental combinations.

Potassium content in the cured leaf was found to improve the burning quality of tobacco. An adequate level of potassium in cured leaf tends to off-set the deleterious effects of high chlorine on burning quality. Cured leaf lacking in potassium content would result in poor coloured trashy leaf and looses its lustre which may not have any commercial value and is very often loose the fire while smoking.

Potassium content was significantly influenced by time of planting, method of curing as well as the interaction between these two factors (Table 2). 
Plate.1 AG grade tobacco leaf

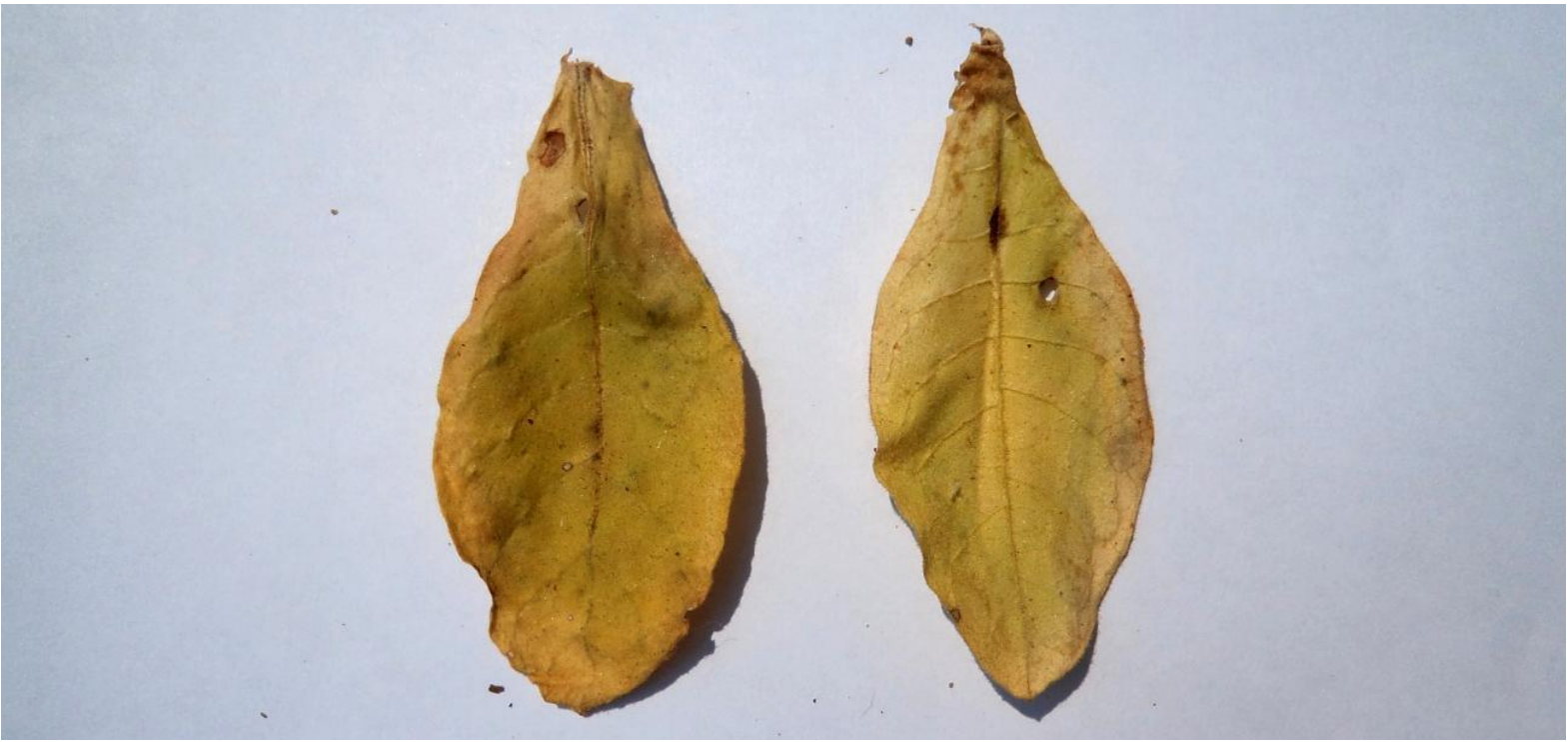

Plate.2 Kappa grade tobacco leaf

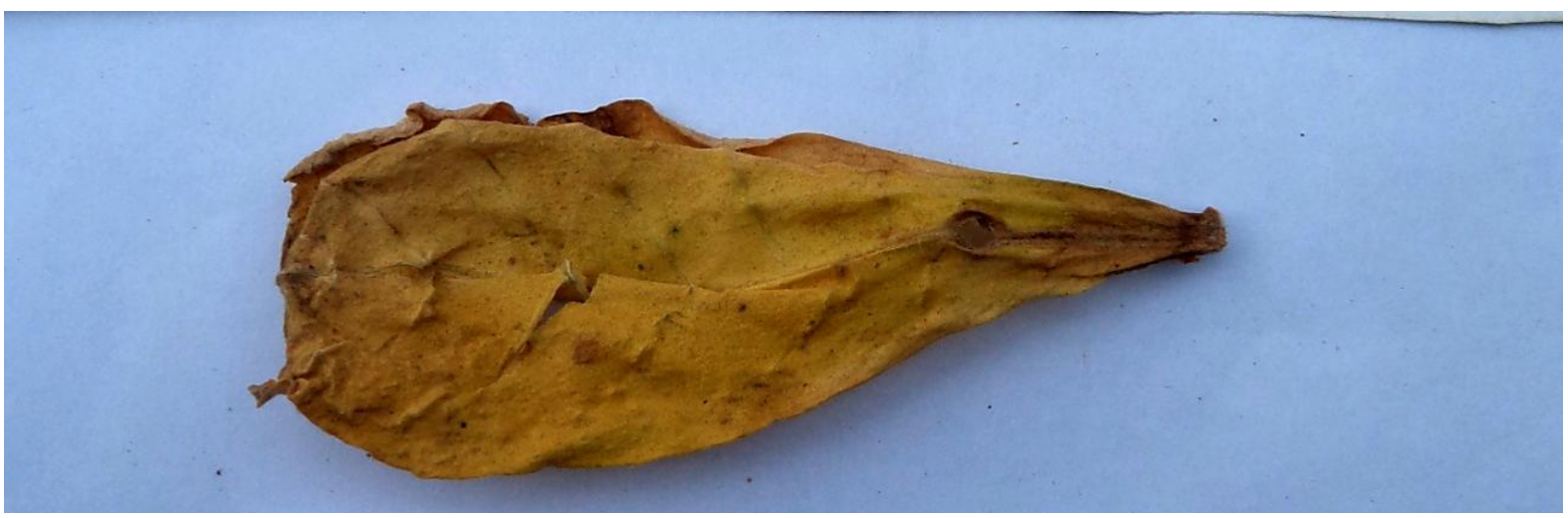

Plate.3 Double Kappa grade tobacco leaf

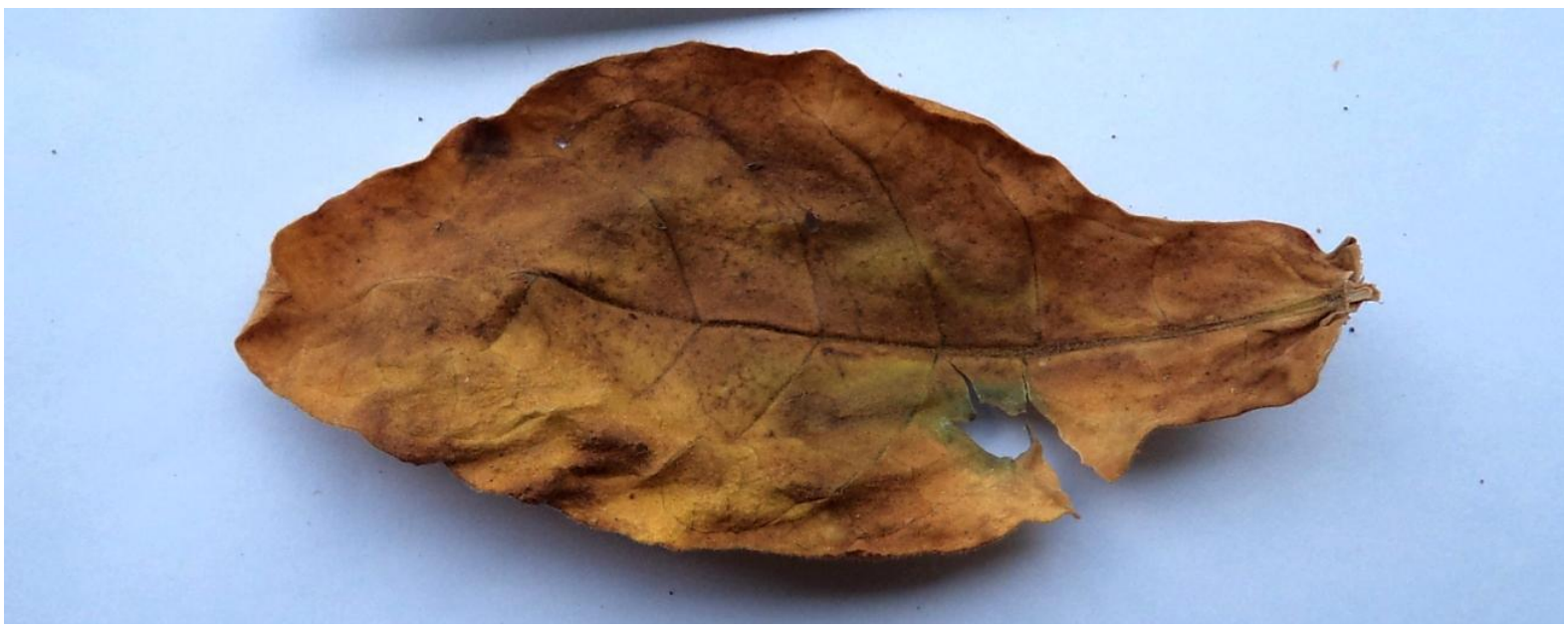


Plate.4 ND grade tobacco leaf

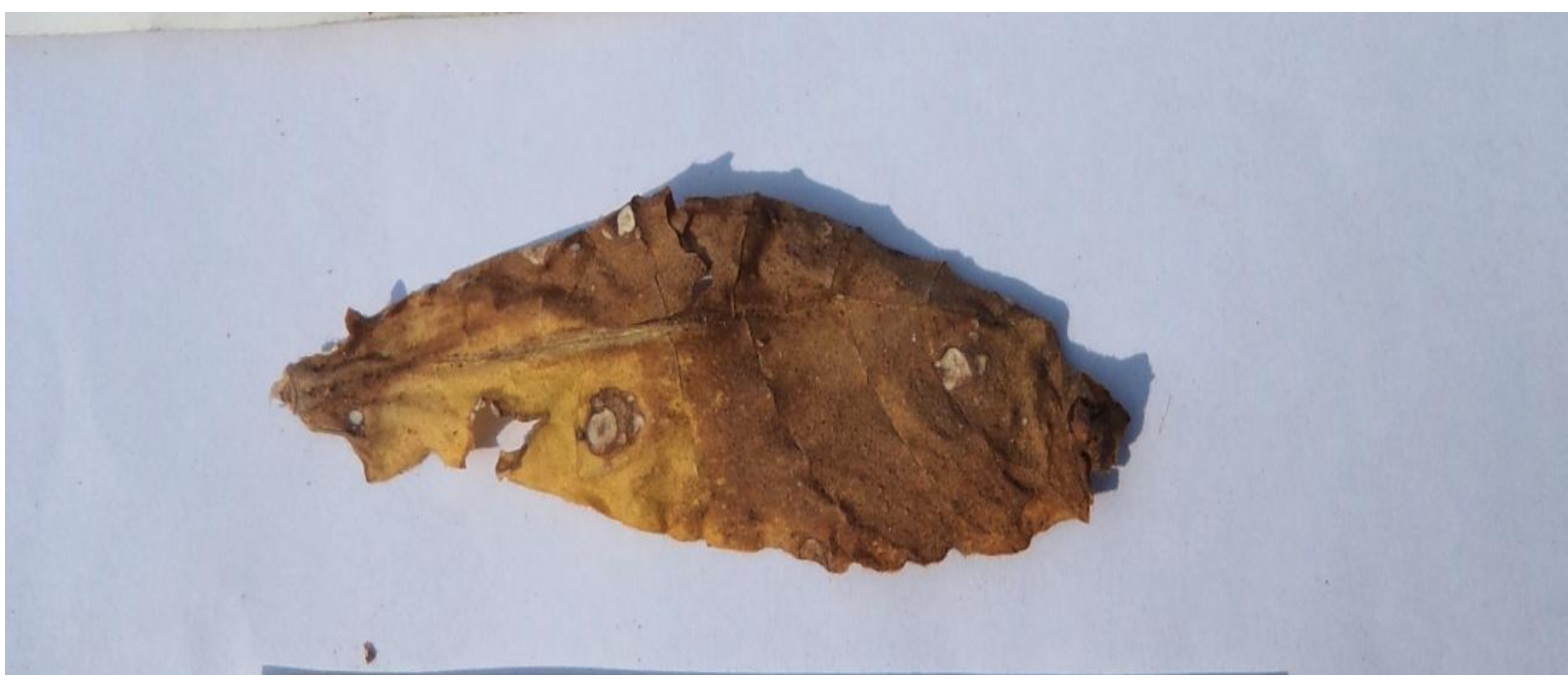

Table.1 Different grades of oriental tobacco based on leaf colour

\begin{tabular}{|c|c|l|}
\hline GRADE & NOMENCLATURE & \multicolumn{1}{|c|}{ DESCRIPTION } \\
\hline 01 & AG & $\begin{array}{l}\text { A premium grade and most preferred tobaccos having } \\
\text { good ripeness, lemon yellow to lemon green color range } \\
\text { and having zero blemish, always fetches top price. It } \\
\text { generally raises from upper portion of the plant (Ucs and } \\
\text { Ucalthis). }\end{array}$ \\
\hline 02 & BG & $\begin{array}{l}\text { A premium grade emanating from middle portion of the } \\
\text { plant, generally from 2nd and 3rd primings (Anas-I \& } \\
\text { II). BG should have good ripeness, lemon yellow to } \\
\text { lemon green having zero blemish. Pricing is slightly } \\
\text { lesser than that of AG. }\end{array}$ \\
\hline 03 & KAPPA & $\begin{array}{l}\text { Kappa (medium grade) emanates from Anas-I and Anas- } \\
\text { II (2nd \& 3rd priming) having good ripe character to } \\
\text { mature nature. Color ranging from Lemon green to } \\
\text { yellow having blemish on the cured leaf. Pricing } \\
\text { followed by BG. }\end{array}$ \\
\hline 04 & DOUBLE KAPPA & $\begin{array}{l}\text { KK is a low (KK) grade generally emanating from dips } \\
\text { (bottom leaves or 1st priming). Sometimes second, third } \\
\text { and fourth priming also produces KK grade due to } \\
\text { defective curing and discouraged to produce. Have more } \\
\text { than 35\% blemish, immature to mature ripeness, } \\
\text { brownish color. Low price paid than Kappa. }\end{array}$ \\
\hline 05 & $\begin{array}{l}\text { It's a (ND) non-descriptive tobacco other than above } \\
\text { parameters and generally produced due to defective } \\
\text { curing. Always paid lowest price for the grade }\end{array}$ \\
\hline \multirow{2}{*}{ ND } &
\end{tabular}


Table.2 Influence of time of planting and method of curing on nicotine content, total sugars and Potassium content (\%) in Oriental tobacco

\begin{tabular}{|c|c|c|c|}
\hline Treatments & Nicotine content & Total sugars & Potassium content \\
\hline \multicolumn{4}{|l|}{ Time of planting } \\
\hline I FN Oct & 0.83 & 20.01 & 0.94 \\
\hline II FN Oct & 0.90 & 19.52 & 1.04 \\
\hline I FN Nov & 1.22 & 16.60 & 0.75 \\
\hline II FN Nov & 1.63 & 14.84 & 0.60 \\
\hline SEm \pm & 0.32 & 0.170 & 0.012 \\
\hline $\mathrm{CD}(\mathrm{P}=\mathbf{0 . 0 5})$ & 0.10 & 0.51 & 0.03 \\
\hline \multicolumn{4}{|l|}{ Curing } \\
\hline Open sun & 1.25 & 16.19 & 0.79 \\
\hline $25 \%$ vent. & 0.99 & 19.55 & 0.88 \\
\hline $50 \%$ vent. & 1.22 & 17.49 & 0.84 \\
\hline SEm \pm & 0.028 & 0.120 & 0.010 \\
\hline $\mathrm{CD}(\mathrm{P}=\mathbf{0 . 0 5})$ & 0.08 & 0.34 & 0.03 \\
\hline \multicolumn{4}{|c|}{ Time of planting $\times$ Curing } \\
\hline $\mathbf{S E m} \pm$ & 0.056 & 0.230 & 0.020 \\
\hline $\mathrm{CD}(\mathbf{P}=\mathbf{0 . 0 5})$ & 0.19 & 0.81 & 0.07 \\
\hline
\end{tabular}


Table.3 Grading proportion (\%) based on leaf colour of oriental tobacco as influenced by time of planting and method of curing

\begin{tabular}{|c|c|c|c|c|}
\hline \multirow{2}{*}{ Treatments } & \multicolumn{4}{|c|}{ Grading proportion (\%) } \\
\cline { 2 - 5 } & $\begin{array}{c}\text { Lemon Yellow } \\
\text { to Lemon } \\
\text { Green (AG) }\end{array}$ & $\begin{array}{c}\text { Lemon Green } \\
\text { to Yellow } \\
\text { (Kappa) }\end{array}$ & $\begin{array}{c}\text { Brownish } \\
\text { (Double } \\
\text { Kappa) }\end{array}$ & $\begin{array}{c}\text { Deep Brown } \\
\text { (ND) }\end{array}$ \\
\hline $\mathrm{T}_{1} \mathrm{C}_{1}$ & - & 79.9 & 16.3 & 3.7 \\
\hline $\mathrm{T}_{1} \mathrm{C}_{2}$ & 22.3 & 62.0 & 12.3 & 3.5 \\
\hline $\mathrm{T}_{1} \mathrm{C}_{3}$ & - & 87.1 & 11.2 & 1.7 \\
\hline $\mathrm{T}_{2} \mathrm{C}_{1}$ & - & 83.7 & 11.3 & 4.9 \\
\hline $\mathrm{T}_{2} \mathrm{C}_{2}$ & 12.5 & 79.7 & 5.0 & 2.8 \\
\hline $\mathrm{T}_{2} \mathrm{C}_{3}$ & - & 84.8 & 12.3 & 2.9 \\
\hline $\mathrm{T}_{3} \mathrm{C}_{1}$ & 2.6 & 90.2 & 7.2 & - \\
\hline $\mathrm{T}_{3} \mathrm{C}_{2}$ & 82.4 & 1.90 & 15.7 & - \\
\hline $\mathrm{T}_{3} \mathrm{C}_{3}$ & 1.0 & 99.0 & - & - \\
\hline $\mathrm{T}_{4} \mathrm{C}_{1}$ & - & 95.1 & 4.9 & - \\
\hline $\mathrm{T}_{4} \mathrm{C}_{2}$ & 61.2 & 38.0 & 0.8 & - \\
\hline $\mathrm{T}_{4} \mathrm{C}_{3}$ & 26.2 & 72.1 & 1.7 & - \\
\hline
\end{tabular}

Scoring is based on \% of grade outturns from total cured leaf yield Data were not analysed statistically

Treatments

Time of Planting

$\mathrm{T}_{1}$ : First Fortnight of October

$\mathrm{T}_{2}$ : Second Fortnight of October

$\mathrm{T}_{3}$ : First Fortnight of November

$\mathrm{T}_{4}$ : Second Fortnight of November

\section{Method of Curing:}

$\mathrm{C}_{1}$ : Open rack under sun

$\mathrm{C}_{2}: 25 \%$ ventilated polyhouse

$\mathrm{C}_{3}: 50 \%$ ventilated polyhouse

Table.4 Total nitrogen, phosphorus and potassium uptake $\left(\mathrm{kg} \mathrm{ha}^{-1}\right)$ at harvest by oriental tobacco as influenced by time of planting

\begin{tabular}{|c|c|c|c|}
\hline \multirow{2}{*}{ Time of planting } & \multicolumn{3}{|c|}{ Crop uptake (kg ha $\mathbf{~}^{-1}$} \\
\cline { 2 - 4 } & Nitrogen & Phosphorus & Potassium \\
\hline I FN Oct & 75.7 & 17.0 & 57.2 \\
\hline II FN Oct & 87.9 & 19.5 & 64.0 \\
\hline I FN Nov & 56.1 & 12.1 & 27.2 \\
\hline II FN Nov & 48.2 & 10.6 & 20.9 \\
\hline
\end{tabular}

* The data was not statistically analysed as curing methods did not show any effect on nutrient uptake 
Fig.1 Nicotine content (\%) of oriental tobacco as influenced by time of planting and method of curing

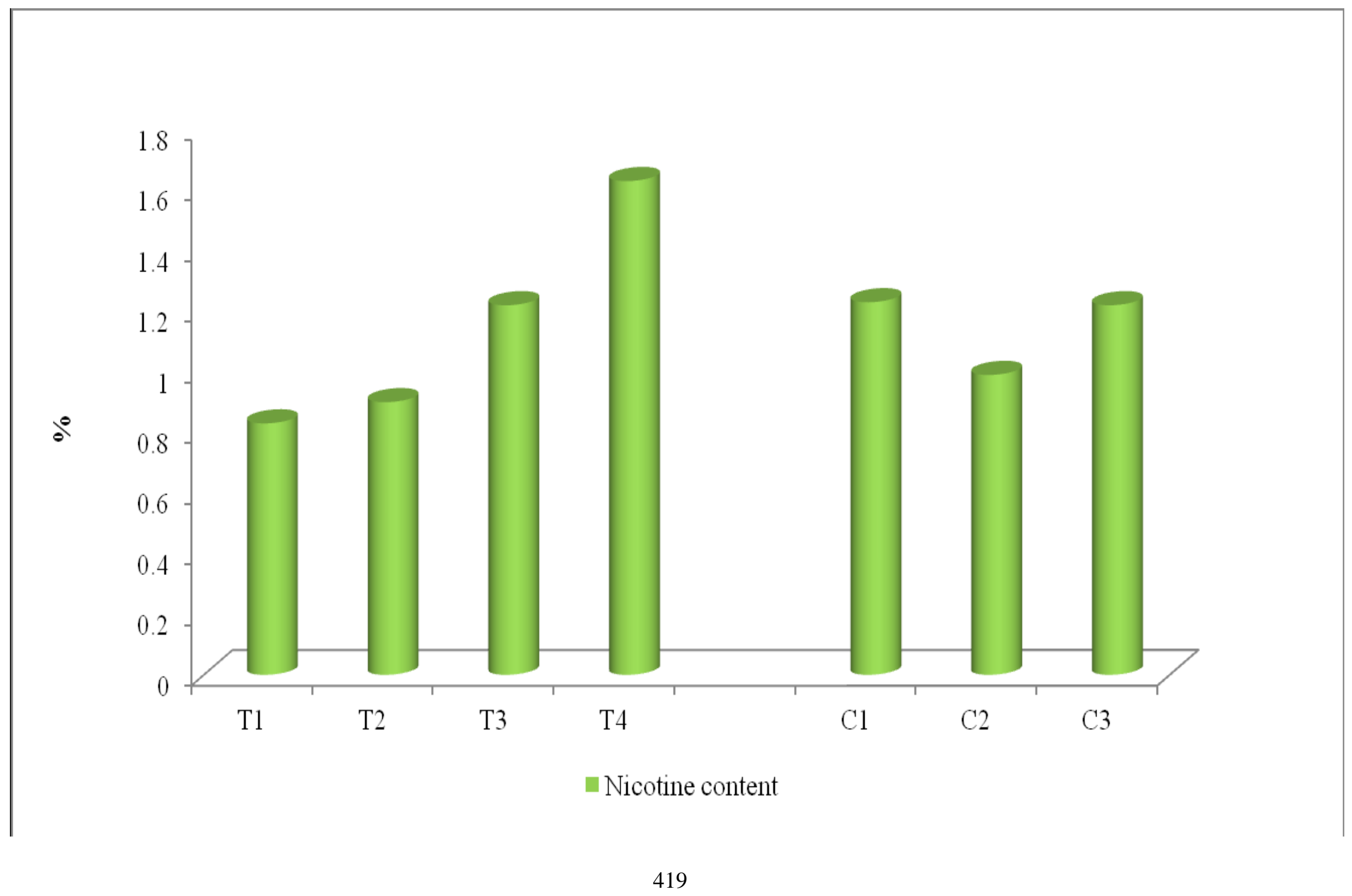




\section{Int.J.Curr.Microbiol.App.Sci (2017) 6(9): 412-427}

Fig.2 Nicotine content $(\%)$ of oriental tobacco as influenced by interaction of time of planting and method of curing

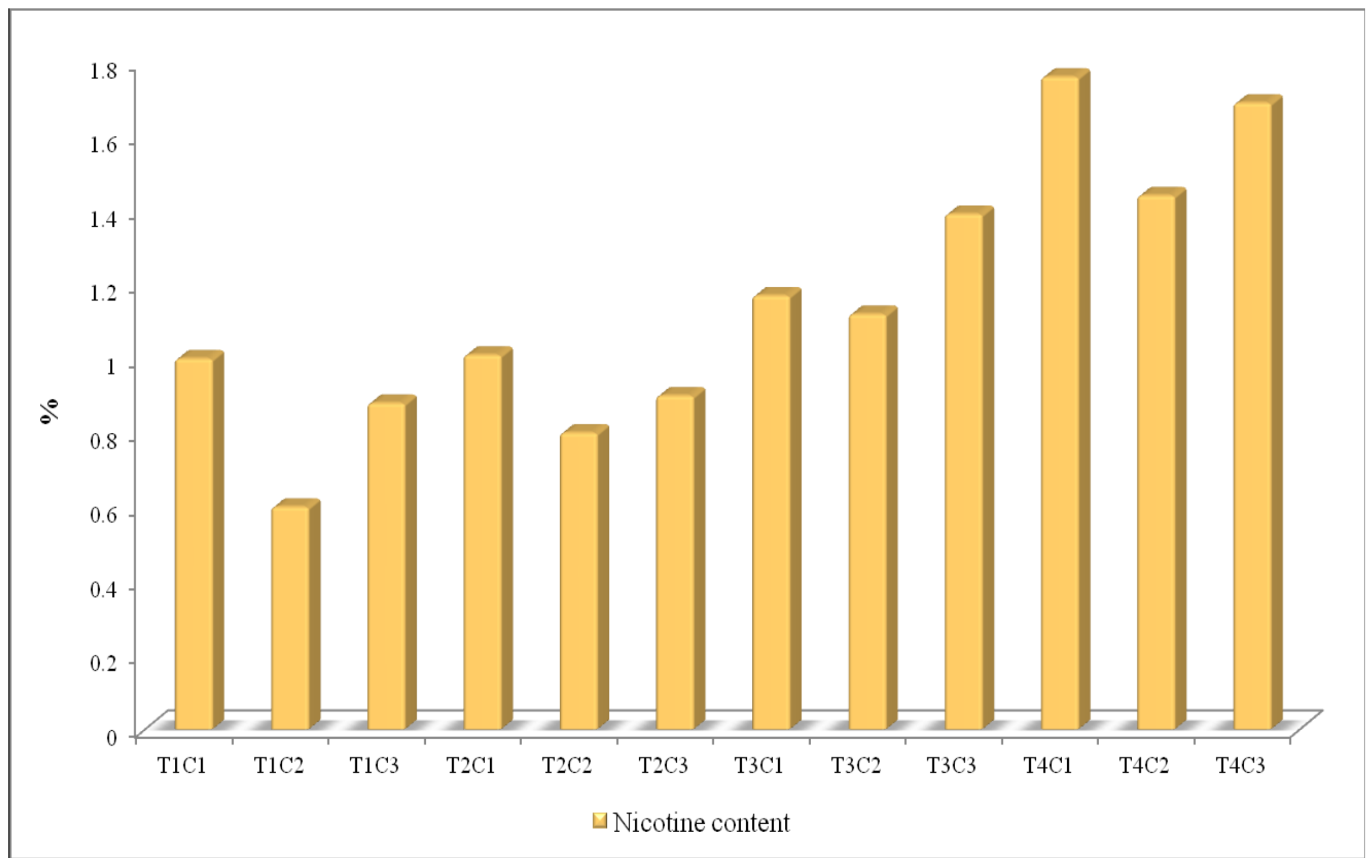


Int.J.Curr.Microbiol.App.Sci (2017) 6(9): 412-427

Fig.3 Total sugars (\%) of oriental tobacco as influenced by time of planting and method of curing

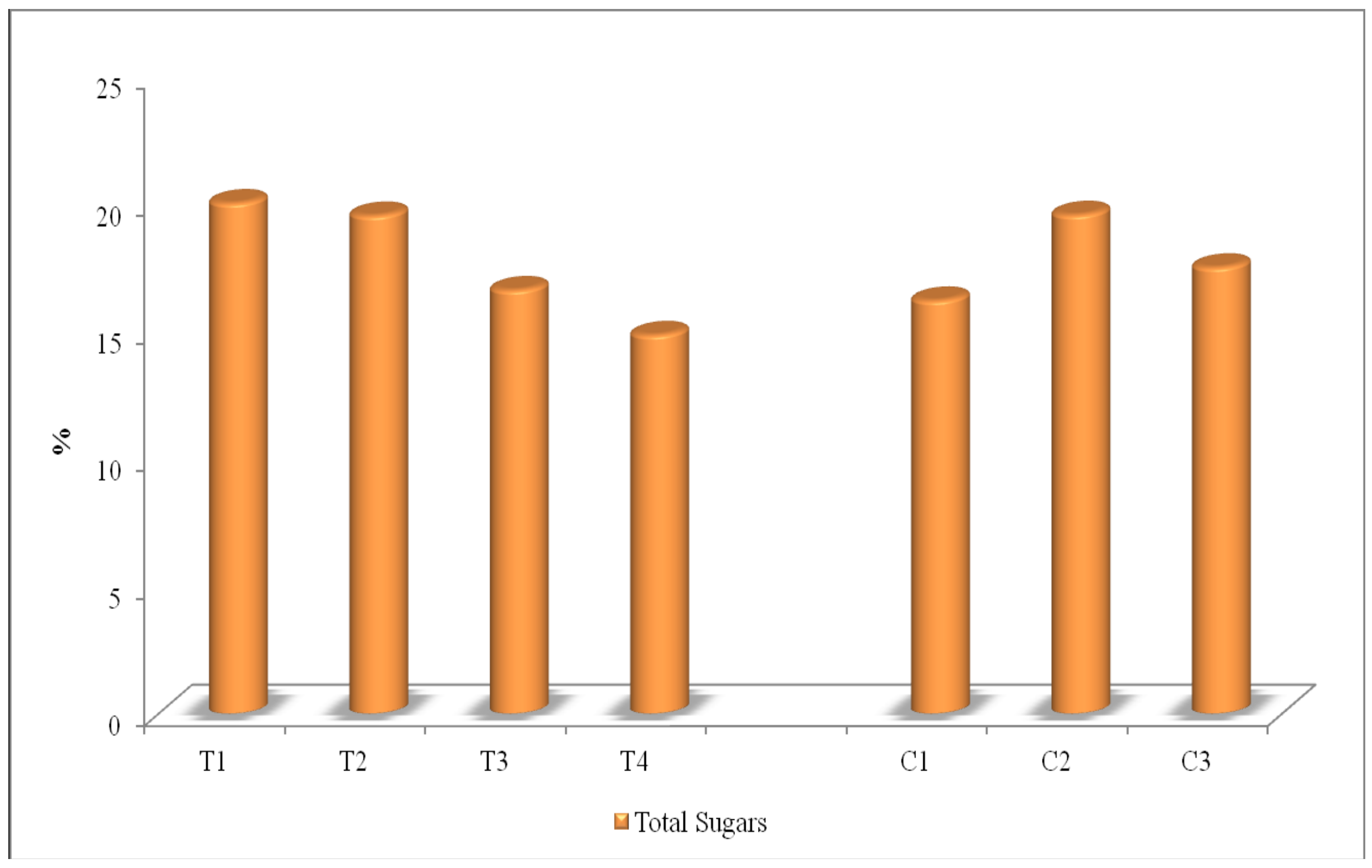


Fig.4 Total sugars (\%) of oriental tobacco as influenced by interaction of time of planting and method of curing

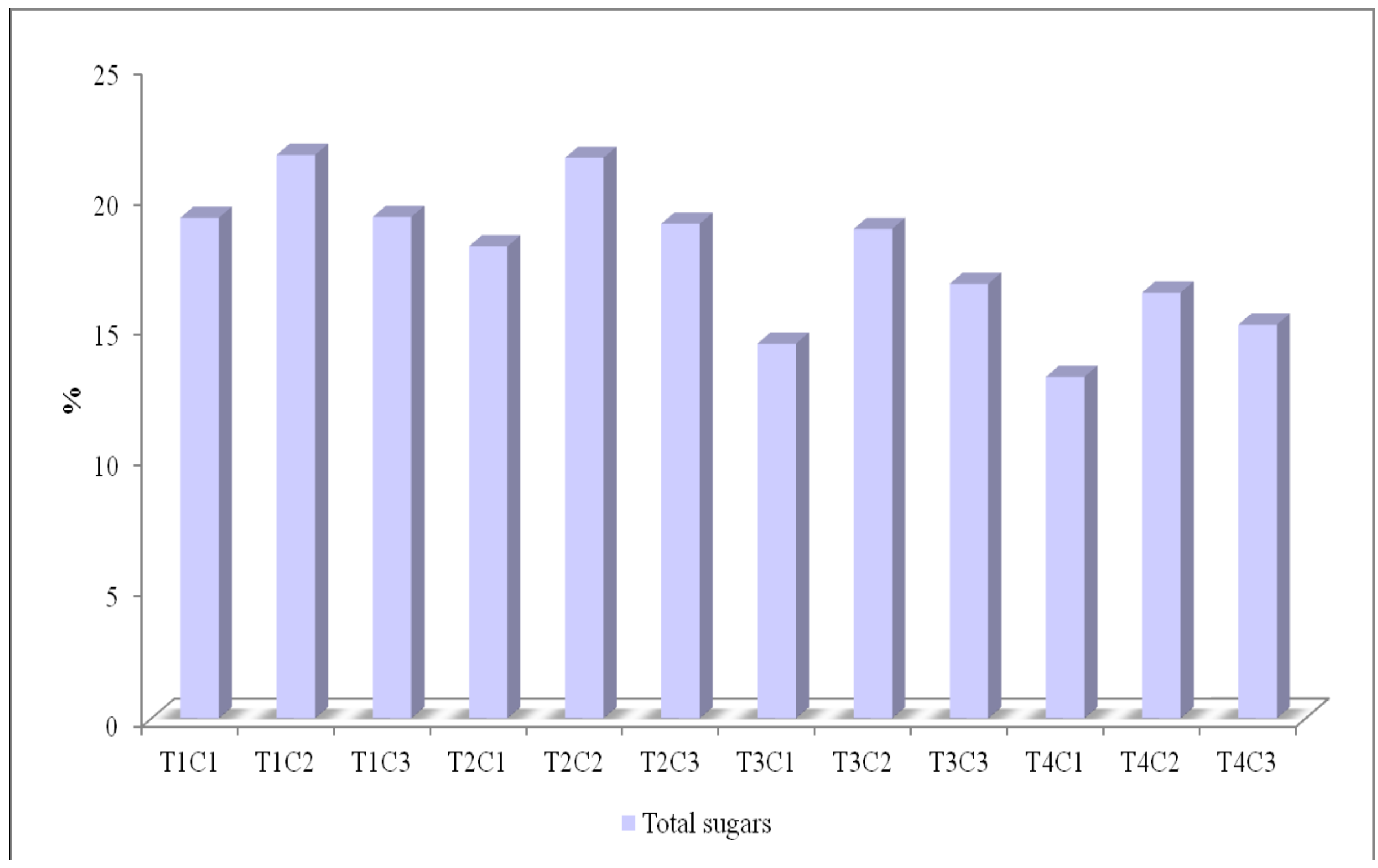


Fig.5 Potassium content (\%) of oriental tobacco as influenced by time of planting and method of curing

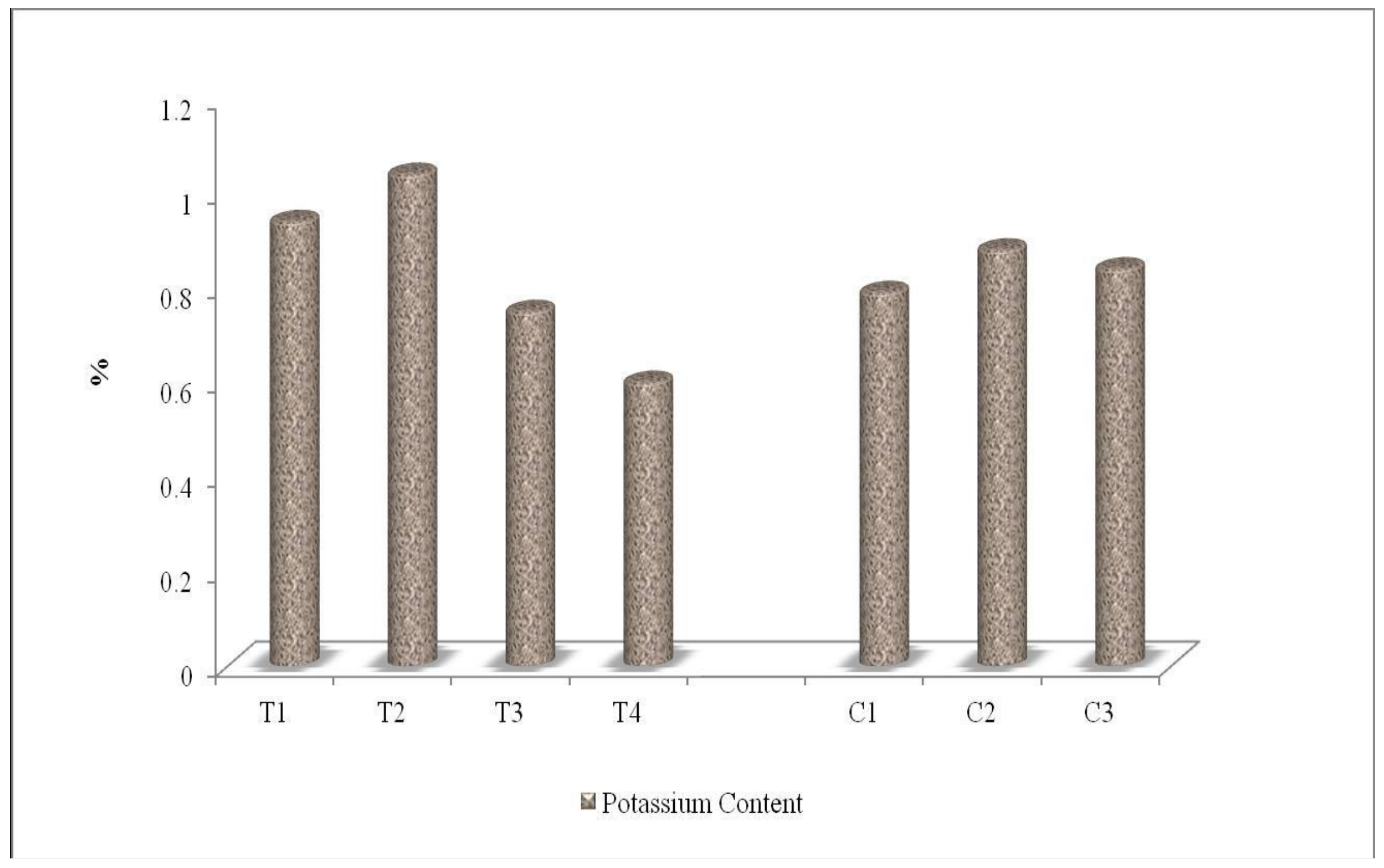


Fig.6 Potassium content $(\%)$ of oriental tobacco as influenced by interaction of time of planting and method of curing

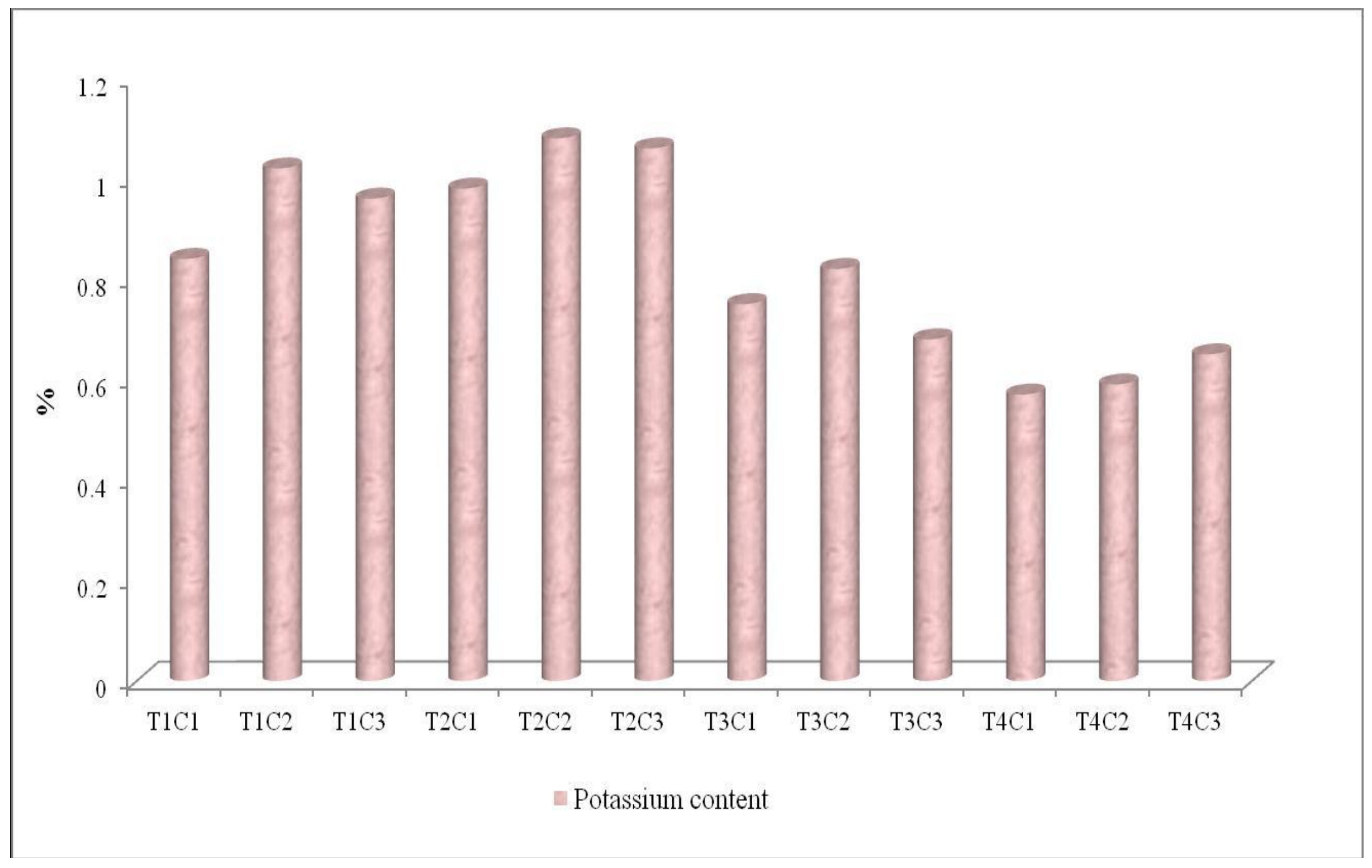


Fig.7 Total Nitrogen, Phosphorus and Potassium uptake $\left(\mathrm{kg} \mathrm{ha}^{-1}\right)$ at harvest by oriental tobacco as influenced time of planting

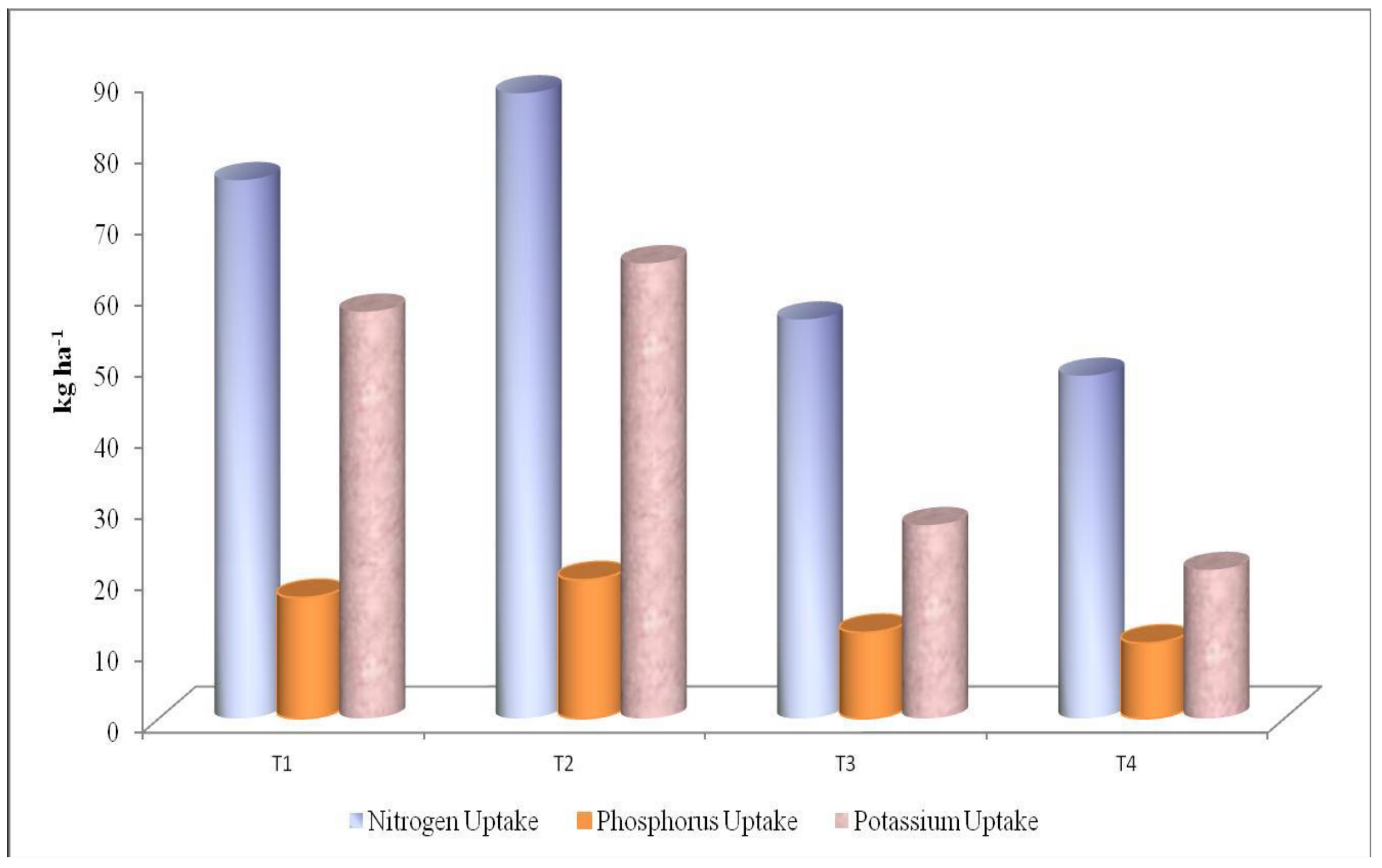


Among the different planting times, the highest potassium content $(1.04 \%)$ was found in the crop planted during second fortnight of October which was significantly higher than the other dates of planting. This might be due to more dry matter production which leads to more potassium uptake. The lowest potassium content $(0.60 \%)$ was recorded in the crop planted during November second fortnight (Fig. 5).

The highest potassium content $(0.88 \%)$ was found in the 25 per cent ventilated polyhouse curing which was significantly superior to other methods of curing. The lowest potassium content $(0.57 \%)$ was recorded in the open rack curing method.

Among the different treatmental combinations, the crop planted during second fortnight of October and 25 per cent ventilated polyhouse curing recorded the highest potassium content $(1.08 \%)$ which was comparable with crop planted in the first fortnight of October with 25 per cent ventilated polyhouse curing. This might be ascribed to the more potassium uptake in the October second fortnight planted crop which has carryover effect even after curing and the mineral salts are crystallized without any loss. The lowest potassium content $(0.59 \%)$ was recorded in the crop planted during November second fortnight and open rack curing method (Fig. 6).

Leaf color is an important feature of tobacco due to its close association with the perceived quality. The grading of leaves into different categories is done on the basis of leaf colour (Plate 1, 2, 3 and 4; Table 3).

The time of planting has not shown any influence on the leaf colour as the leaf colour is determined by method of curing.

The method of curing exerted a significant influence on the leaf colour. The colour of leaf is better in the 25 per cent ventilated polyhouse curing method compared to other methods of curing. As the uniform and slow curing helps in accumulation of neutral volatile compounds and polyphenols which imparts development of uniform leaf colour. The leaf colour was poor in the open rack curing method which might be ascribed to fast drying and bleaching action of direct bright sun light. Inferior leaf quality under sun curing was also reported by Sinha et al., (1985) in chewing tobacco and Dulay et al., (1987) in burley tobacco.

The planting time significantly influences the nutrient uptake in oriental tobacco (Table 4). Among the different dates of planting, the highest nitrogen, phosphorus and potassium uptake was observed in the crop planted during second fortnight of October which was higher than the other dates of planting (Fig. 7). This might be due to well distributed rainfall during the crop growth period resulting in increased moisture availability leading to more dry matter production. The better moisture availability helps in absorption of larger quantities of nutrients and has positive correlation with dry matter production and concentration of nutrients in the plant. The lowest nutrient uptake was observed in the crop planted during second fortnight of November is due to lower dry matter per unit area coupled with lower nutrient content.

From the experiment it can be inferred that planting oriental tobacco during October second fortnight with 25 per cent ventilated polyhouse curing has resulted in higher productivity, superior quality.

\section{References}

Bae, S.K., 1987. Studies on the prevention of excessive drying leaves during burley tobacco curing, 3; Effect of ventilating conditions on the occurrence of 
excessive curing leaves. Korean Journal of Crop Science. 32(2): 130136.

CORESTA, recommended method No35. 1994. Determination of total alkaloids (as nicotine) in tobacco by continuous flow analysis. www.coresta.com.

CORESTA, recommended method No37.1994. Determination of reducing substances in tobacco by continuous flow analysis. www.coresta.com.

Dulay, J.A., Capuno, V.T., Castro, R.C and Cabigan, C.A. 1987. Evaluation of the methods of curing burley tobacco. Journal of Tobacco Science and Technology. 1(4): 372-378.

Jackson, M.L., 1973. Soil chemical analysis. Prentice Hall of India Pvt. Ltd. New Delhi. pp. 134-204.

Long, R.C., and Woltz, W.G. 1972. Depletion of nitrate reductase activity in response to soil leaching. Agronomy Journal. 64: 789-792.

Papenfus, H.D., and Quin, F.M. 1984. Tobacco In: The physiology of Tropical Food Crops, (eds. P.R. Goldsworthy and N.M. Fisher) 607-36 John Wiley and Sons, New York.

Phillips, R.E., Leggett, J.E., Chaplin, J.F and Zeleznik, J.M. 1991. Effect of water stress on growth, assimilation and partitioning of carbon and nitrogen in burley tobacco. Tobacco Research. 35: 22-27.

Prasada Rao, E., Koteswara Rao, D.S., Anjaneyulu, C., Sumathi, V and Ravi, V. 2002. Yield and quality of oriental tobacco as affected by time of planting and pattern of planting. Tobacco Research. 28(2): 152-155.

Reynolds, L.B., and Rosa, N. 1995. Effects of irrigation scheduling and amounts on flue-cured tobacco in Ontario. Tobacco Research. 39: 83-91.

Sinha, R., Dwivedi, S.S.L and Pandey, A.K. 1985. Effect of method of harvesting and curing on the yield and quality of chewing tobacco. Tobacco Research. 11(1): 28-34.

Sreeramulu, E., Maheswara Reddy, $\mathrm{P}$ and Sampath Kumar, D. 2000. Yield and quality of oriental tobacco as influenced by time of planting and manurial levels in Andhra Pradesh. Tobacco Research. 26(1): 20-24

Weybrew, J.A., Wan Ismail, W A and Long R C 1983. The cultural management of flue-cured tobacco quality. Tobacco Science. 27: 56-61. www.tobacco reporter.com, 2012.

\section{How to cite this article:}

Ranga Nethaji, P. and Reddi Ramu, Y. 2017. Influence of Time of Planting and Method of Curing on Quality Parameters and Nutrient Uptake in Oriental Tobacco (Nicotiana tabacum). Int.J.Curr.Microbiol.App.Sci. 6(9): 412-427. doi: https://doi.org/10.20546/ijcmas.2017.609.050 